\title{
First Record of the Southern Flying Lizard, Draco dussumieri (Duméril and Bibron 1837), from the Western Ghats of Maharashtra, India
}

\author{
Anish Pardeshi ${ }^{1}$ and Makarand Naik ${ }^{2}$
}

${ }^{1}$ Malabar Nature Conservation Club, Amboli, Maharashtra, India (anishpardeshi103@gmail.com)
${ }^{2}$ At post Sareli, Taluka Dodamarg, District Sindhudurg, Maharashtra, India (mkrndnaik@gmail.com)

T he flying lizards of the genus Draco (family Agamidae) are widely distributed in southeastern Asia and southwestern India (McGuire and Dudley 2011). Draco dussumieri was first described by Duméril and Bibron in 1837 based on specimens collected from Malabar (present day region of northern Kerala, India; Smith 1935). These are diurnally active, arboreal lizards endemic to the Western and Eastern Ghats of India. Records exist for the states of Goa, Karnataka, Kerala, Tamil Nadu, and southern Andhra Pradesh, where this species is widely distributed in protected areas and reserve forests (Smith 1935; John 1962; Johnson 1983; Inger et al. 1984; Sugathan 1984; Das and Whitaker 1990; Zacharias 1997; Balachandran 1998; Kannan and Venkataraman 1998; Balachandran and Pittie 2000; Cherian et al. 2000; Ishwar et al. 2001; Ishwar et al. 2003; Sreedharan 2004; Krishnan 2008; Venugopal 2010).

At about $1230 \mathrm{~h}$ during a field survey on 28 May 2015 in the Tillari Forest Region of Maharashtra, India $\left(15^{\circ} 41^{\prime} \mathrm{N}\right.$, $74^{\circ} 12^{\prime} \mathrm{E}$; elevation $115 \mathrm{~m}$ asl), we encountered two lizards in a tree more than $2 \mathrm{~m}$ above the ground (Fig. 1). We identified

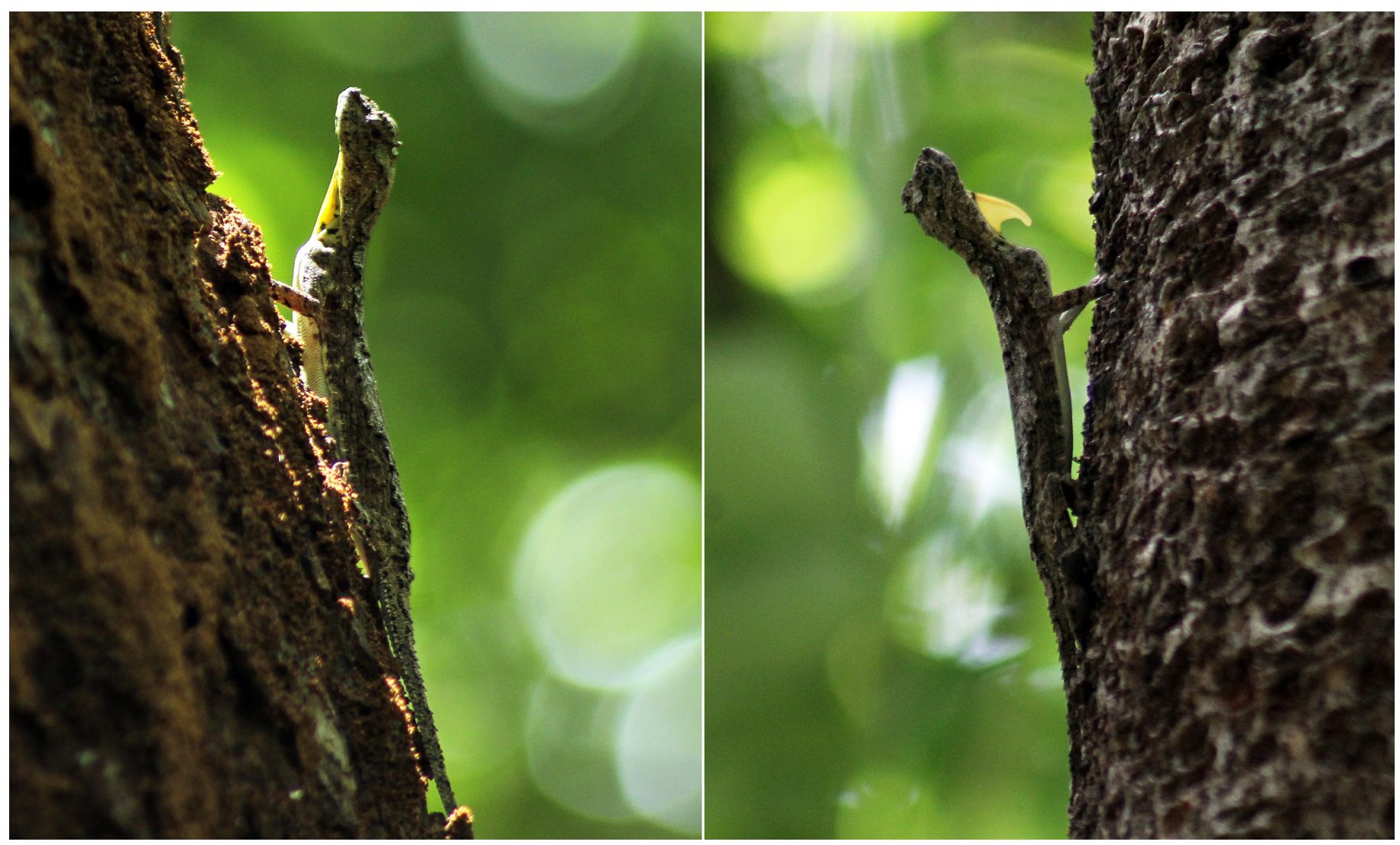

Fig. 1. Southern Flying Lizards (Draco dussumieri) in the Tillari Forest, Maharashtra, India. Photographs by Makarand Naik. 
them as Southern Flying Lizards (Draco dussumieri) by the presence of the elongated, bright lemon-yellow dewlap, the patagium patterned beneath with black blotches, the hornlike conical tubercles behind and above the eyes, the rugose dorsum, and the irregular brown spots on the throat (Günther 1864; Boulenger 1890; Smith 1935; Daniels 2002). The forests in this area are semi-evergreen and moist deciduous (Jog 2009).

The Tillari Forest Region is located in the Dodamarg Taluka in the Sawantwadi Subdivision of the Sindhudurg District, Maharashtra, India. The previously recorded distribution of $D$. dussumieri in the Western Ghats was limited to the states of Goa, Karnataka, Tamil Nadu, and Kerala (Daniels 2002). This observation extends the range of this species north by $25 \mathrm{~km}$ (aerial) and is a first record from the state of Maharashtra.

Draco dussumieri is listed as of Least Concern on the IUCN Red List (Srinivasulu et al. 2013) because it is widely distributed and fairly common throughout its range. However, the habitat of the locality described herein is affected by massive rubber and cashew nut plantations. Additional field surveys are necessary for delimiting the northernmost distribution of this species in the Western Ghats.

\section{Acknowledgements}

We thank Girish Punjabi, Harshal Bhosle, Raman Kulkarni, Faruk Mhetar, Kaka Bhise, Prashant Jadhav, Pravin Desai, and Ashwini Joshi for their constant support and motivation. We also thank Rutuja Pardeshi for useful comments that improved this manuscript.

\section{Literature Cited}

Balachandran, S. 1998. Golden Oriole Oriolus oriolus preying on flying lizard Draco dussumieri Dum. \& Bibr. Journal of the Bombay Natural History Society 95: 115.

Balachandran, S. and A. Pittie. 2000. Occurrence of Draco or flying lizard Draco dussumieri in Chittoor District, Andhra Pradesh. Journal of the Bombay Natural History Society 97: 147-148.

Boulenger, G.A. 1890. The Fauna of British India, Including Ceylon and Burma. Reptilia and Batrachia. Taylor and Francis, London, UK.
Cherian, P.T., K. Rema Devi, and M.S. Ravichandran. 2000. Ichthyo and herpetofaunal diversity of Kalakkad Wildlife Sanctuary. Zoos' Print Journal 15: 203-206.

Daniel, J.C. 2002. The Book of Indian Reptiles and Amphibians. Oxford University Press, Oxford, UK.

Das, I. and R. Whitaker. 1990. Herpetological investigations in the Western Ghats, south India. Part I. The Vanjikadavu and Nadukani forests, Kerala State. Hamadryad 15: 6-9.

Günther, A.C.L.G. 1864. The Reptiles of British India. Taylor and Francis, London, UK.

Inger, R.F., H.B. Shaffer, M. Koshy, and R. Bakde. 1984. A report on a collection of amphibians and reptiles from the Ponmudi, Kerala, South India. Journal of the Bombay Natural History Society 81: 551-570.

Ishwar, N.M., R. Chellam, and A. Kumar. 2001. Distribution of forest floor reptiles in the rainforest of Kalakad-Mundanthurai Tiger Reserve, South India. Current Science 80: 413-418.

Ishwar, N.M., R. Chellam, A. Kumar, and B.R. Noon. 2003. The response of agamid lizards to rainforest fragmentation in southern Western Ghats, India. Conservation and Society 1: 69-86.

Jog, S.K. 2009. Sahyadris - Flora and Ethnobotany. Unpublished report, University of Texas at Tyler, Tyler, Texas, USA.

John, K.O. 1962. Notes on the bionomics of the flying lizard, Draco dussumieri Dum. \& Bib. Journal of the Bombay Natural History Society 59: 298-301.

Johnson, J.M. 1983. On flying lizard in Mundunthurai Sanctuary. Journal of the Bombay Natural History Society 80: 229-230.

Kannan, P. and C. Venkataraman. 1998. Reptile fauna of Siruvani Hills, Nilgiri Biosphere Reserve, Tamil Nadu. Cobra 33: 6-9.

Krishnan, S. 2008. New species of Calotes (Reptilia: Squamata: Agamidae) from the southern Western Ghats, India. Journal of Herpetology 42: 530-535.

McGuire, J.A. and R. Dudley. 2011. The biology of gliding in flying lizards (genus Draco) and their fossil and extant analogs. Integrative and Comparative Biology 51: 983-990.

Smith, M.A. 1935. The Fauna of British India, Including Ceylon and Burma. Reptilia and Amphibia, Vol. II.-Sauria. Taylor and Francis, London, UK.

Sreedharan, T.P. 2004. Biological Diversity of Kerala: A survey of Kalliasseri panchayat, Kannur district. Discussion Paper No. 62. Kerala Research Programme on Local Level Development, Centre for Development Studies, Thiruvananthapuram, India.

Srinivasulu, C., B. Srinivasulu, S.P. Vijayakumar, M. Ramesh, S.R. Ganesan, M. Madala, and R. Sreekar. 2013. Draco dussumieri. The IUCN Red List of Threatened Species 2013: e.T172625A1354495.

Sugathan, R. 1984. Occurrence of flying lizard (Draco dussumieri) in the Nilgiris. Journal of the Bombay Natural History Society 81: 710.

Venugopal, P.D. 2010. Population density estimates of agamid lizards in humanmodified habitats of the Western Ghats, India. The Herpetological Journal 20: 69-76.

Zacharias, V.J. 1997. Reptiles of Periyar Tiger Reserve, Kerala. Journal of the Bombay Natural History Society 94: 575-579. 